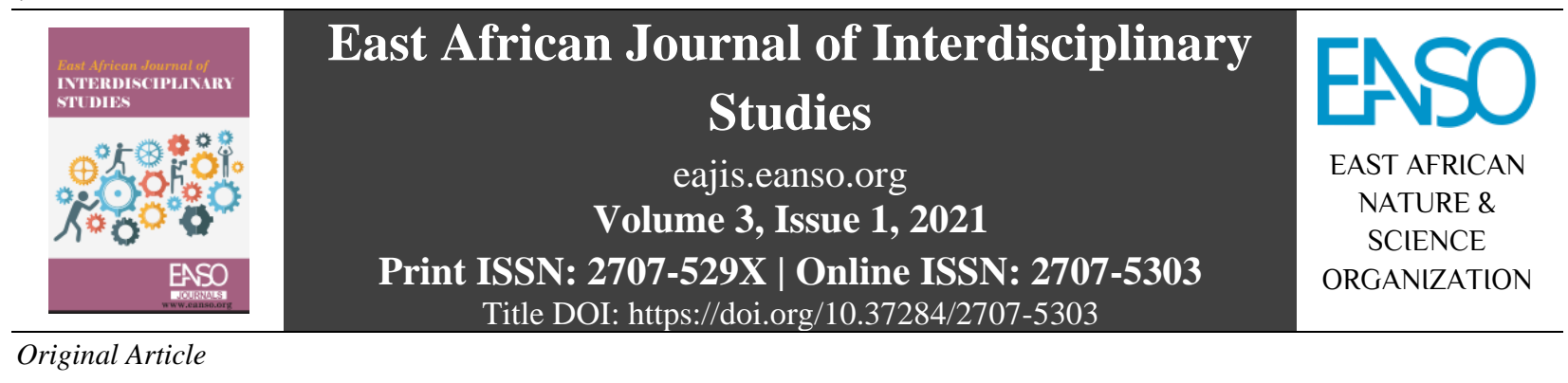

\title{
Role of Tutors' Social Reconstruction Orientation on Choice of Instructional Approaches in Public Primary Teachers' Training Colleges in Kenya
}

\author{
Jacinta Katumbe Mutisya ${ }^{*}$, Wilfrida Arnodah Itolondo, $P h D^{1} \&$ Samson Kariuki Ikinya, PhD ${ }^{1}$ \\ ${ }^{1}$ Department of Educational Management, Policy and Curriculum Studies, Kenyatta University, P. O. BOX 43844-00100, Nairobi. \\ * Author for Correspondence Email: jacikinyua@ gmail.com.
}

Article DOI: https://doi.org/10.37284/eajis.3.1.268

\section{Date Published: ABSTRACT}

11 January 2021 Education acts as an instrument of social reconstruction and therefore, it must be capable of stabilising social order and conserving culture in the

Keywords: society to ensure sustainability. Tutor beliefs about a curriculum for social changes and adaptability upon which social reconstruction

Social Reconstruction

Orientation,

Instructional

Approaches,

Social Competences,

Integration of Societal

Issues,

Teacher Education

Curriculum,

Tutors,

Primary Teacher

Training Colleges. orientation is premised is vital in developing knowledge, skills, attitudes and values in teacher trainees is much needed to adapt to the everchanging global demands. This study sought to determine tutors' preference on the choice of instructional approaches; to determine tutors' level of social reconstruction orientation to the teacher education curriculum and to establish the relationship between tutors' social reconstruction orientation and choice of instructional approaches in public primary teacher training colleges in Kenya. This study adopted a correlational approach with a convergent mixed-methods approach. Questionnaires, interviews, classroom observation and document analysis were used to collect data. The sample population involved 178 tutors, 35 HODs, 20 classrooms and 4 documents purposively selected from five public primary teacher training colleges in Kenya. Both descriptive and inferential statistics were used to analyse data as per the study objectives. The study found no significant relationship between social reconstruction orientation and choice of instructional approaches. Consequently, this may impact negatively on the development of a teacher that is engaged, empowered, ethical and globally competitive as is proposed in the current teacher education reforms in Kenya. The inadequate representation, the restricted framework, limited provision of interactive learning activities and policy on the integration of societal issues in the primary teacher education curriculum provided a poor link between theory on societal issues and practice. Professional development of tutors and relevant stakeholder engagement are crucial 
in changing the mindsets of tutors with regard to teaching a curriculum for social reconstruction.

\section{APA CITATION}

Mutisya, J. K., Itolondo, W. A., \& Ikinya, S. K. (2021). Role of Tutors' Social Reconstruction Orientation on Choice of Instructional Approaches in Public Primary Teachers' Training Colleges in Kenya. East African Journal of Interdisciplinary Studies, 3(1), 12-26. https://doi.org/10.37284/eajis.3.1.268.

\section{CHICAGO CITATION}

Mutisya, Jacinta Katumbe, Wilfrida Arnodah Itolondo, and Samson Kariuki Ikinya. 2021. "Role of Tutors' Social Reconstruction Orientation on Choice of Instructional Approaches in Public Primary Teachers' Training Colleges in Kenya". East African Journal of Interdisciplinary Studies 3 (1), 12-26. https://doi.org/10.37284/eajis.3.1.268.

\section{HARVARD CITATION}

Mutisya, J. K., Itolondo, W. A., and Ikinya, S. K. (2021) "Role of Tutors' Social Reconstruction Orientation on Choice of Instructional Approaches in Public Primary Teachers' Training Colleges in Kenya", East African Journal of Interdisciplinary Studies, 3(1), pp. 12-26. doi: 10.37284/eajis.3.1.268.

\section{IEEE CITATION}

J. K. Mutisya, W. A. Itolondo, and S. K. Ikinya, "Role of Tutors' Social Reconstruction Orientation on Choice of Instructional Approaches in Public Primary Teachers' Training Colleges in Kenya”, EAJIS, vol. 3, no. 1, pp. 12-26, Jan. 2021.

\section{MLA CITATION}

Mutisya, Jacinta Katumbe, Wilfrida Arnodah Itolondo, and Samson Kariuki Ikinya. "Role of Tutors' Social Reconstruction Orientation on Choice of Instructional Approaches in Public Primary Teachers' Training Colleges in Kenya". East African Journal of Interdisciplinary Studies, Vol. 3, no. 1, Jan. 2021, pp. 12-26, doi:10.37284/eajis.3.1.268.

\section{INTRODUCTION}

Social reconstruction orientation looks upon the curriculum as a driving force to changes in society. As such the type of education offered in schools should be capable of stabilising social order and conserving culture in the society (Shrivastava, 2017). The main focus of a tutor whose curriculum orientation is social reconstruction is on developing social competencies and values that will enable the trainee to understand the prospects of the society he or she lives in (Schiro, 2013). Social reconstruction orientation lays emphasis on issues that face society (Hunkins \&Ornstein 2016). According to Sukri et al. (2018), a social reconstruction curriculum should provide opportunities for collaborative interaction between learners and their peers, learners and the teachers, learners and their environment and other learning resources so as to develop socially adaptive behaviours and competencies that enable them to solve social problems. Such a curriculum is grounded on the understanding of issues that are pertinent and contemporary in the society as well as the social-cultural norms of a society.

In social reconstruction orientation, curriculum relevancy is determined by content that takes into consideration issues, policies, resources and facilities existing in the society and the challenges members face in addressing, sharing and making appropriate use of them (Abakay, Şebin, \& Şahin, 2013; Brendan, 2016). Tutors oriented to social reconstruction use issues emerging in the society such as diseases, pollution, corruption, and unemployment to enable students to make informed judgments and act on them (Bay et al., 2012; Abakay, Şebin, \& Şahin, 2013). Tutors' social reconstruction orientation is critical in addressing emerging curriculum issues in line with the competency-based 
curriculum in primary teacher training colleges. Social reconstruction orientation is useful in the implementation of a curriculum that is value-based and one that emphasises in inculcating holistic, meaningful and sustainable education (KICD, 2019).

Mills (2012), Mayne (2014) and Reddy (2014) contended that teacher education programs should incorporate social issues to enable students to develop their social identities, reflect on experiences, values and perspectives of teaching and learning. Tutors' lack of commitment to act as agents of social change leads to inadequacies of the preparation or training possessed by students. This is because tutors limit themselves to actively and democratically engaging students in classroom decision-making and in community-based projects that help raise both the tutors' and students consciousness to deal with social problems or promote social change (Lindsay \& Ginsburg, 2013). The USA teacher education course lacks critical engagement with social issues affecting student learning such as social class, race, language and sexuality. However, Ticknor (2015), in her study on what teacher educators in the USA can do to sustain social justice learning found that engaging students in investigations, analysis and evaluation of problems in the society during field experiences helped them develop awareness and sensitivity to the many social issues in the society and they are able to connect how these issues inform their teaching practices. According to Kaur (2012), through the careful coordination of coursework and field experiences, student teachers understand themselves and make sense of their experiences by connecting class assignments and field experiences in meaningful ways.
According to Ballantine and Hammack (2015), content meant for social reconstruction should be drawn from individual skills, interests and abilities, social and cultural traditions and then reflected in the subject matter to be taught. In the United States, the reconstructionist classroom contains a teacher whose role is to advise the students on the research techniques, writing skills, public communication methods and building core skills that are applicable across a wide range of topics (Edupedia, 2018). On the other hand, the students in social reconstructionist classrooms choose topics of their own interest while considering social priorities and use the teacher's guidance to achieve their educational goals (Edupedia, 2018). Consequently, this has helped to maintain social order in the United States while assisting students to achieve academic excellence without compromising their cultural education. Chen and Schmidtcke (2017) recommended that students should be given the opportunity for reflective thinking, selfevaluation and provided with more meaningful learning to enhance their personal growth and civic awareness. The content for the social reconstruction curriculum is seen as relevant in influencing the choice of instructional approaches that would help in nurturing teacher trainees' talents and potentials through the teaching of pertinent and contemporary issues and community service learning.

Broome (2014) argues that tutors should teach beyond facts and concepts and engage students in transformational activities in order to develop their social competencies. Aloni (2013) assert that social competences require more than knowledge and skills and therefore tutors should create warm, caring, multidimensional classrooms that encourage 
students to debate alternatives to controversial social issues, incorporate collaborative learning experiences and set up projects that emphasise on developing creativity, problemsolving, critical thinking and responsibility skills. Ashour et al. (2012) in their study on curriculum orientation of pre-service teachers in Hashemite University, Jordan found that fostering students' ability to criticise societal problems and create a new and healthy society was vital in enhancing the quality of learning and academic excellence of students. According to Mosley (2010) and Orpinas (2010), Social competence is premised on a wide range of cognitive abilities, emotional processes, behaviours skills, and social awareness, personal and cultural values that enable individuals to socially adjust and make informed decisions on issues that challenge and affect them. The beliefs and assumptions tutors hold with regard to a social reconstruction curriculum will likely impact the choice of instructional approaches they use in classroom teaching. Consequently, this will contribute to the quality of teacher education and the development of a generation of citizens that can amicably address challenges they face in society on a daily basis.

\section{Statement of the Problem}

Education for sustainable development policy in Kenya (2017) provides, promotes and coordinates quality lifelong education, training, research and innovation. Tutors are powerful agents of social change and promoting education for sustainable development is a key factor in enabling sustainable development and quality education. Despite the government's effort in improving the quality of teacher education by producing holistic individuals who are professionally competent, committed and readily adjustable to social challenges, the education sector is still faced with a myriad of challenges emanating from socially related issues such as drug abuse, early pregnancies, lack of employment and other discipline related issues. Similarly, despite pedagogical leadership training offered to improve tutors' instructional approaches and improve on their innovativeness in classroom teaching through in-service training initiatives, tutors have continued to use teacher-centred instructional approaches as opposed to learner-centred instructional approaches that are more preferred. This brings into question whether tutors are oriented towards the teaching of social knowledge, skills, values and attitudes that has a bearing on all spheres of life including teacher education in modern society. This is a vital concern if the teacher education objectives on producing an engaged, empowered, ethical and globally competitive citizen are to be achieved. This study therefore investigated the role played by tutors' social reconstruction orientation on the choice of instructional approaches they used for purposes of improving the quality of teacher education in public primary teacher training colleges in selected colleges in Kenya.

\section{MATERIALS AND METHODS}

The study was conducted in five public primary teachers' training colleges in Kenya, namely: Aberdare, Kamwenja, Kilimambogo, Murang'a and Thogoto between May 2019 and March 2020. This study used a correlational research design that employed a convergent parallel mixed-methods approach. According to Creswell (2012), a correlational research design is appropriate when the researcher 
wants to describe and measure the degree of association between two or more variables without manipulating any of the variables. The study utilised a convergent parallel mixedmethods approach to collect quantitative and qualitative data for purposes of corroborating and validating findings. Quantitative data were collected using questionnaires while qualitative data was collected using interviews, observation and document analysis.

The entire population of 199 tutors in the five primary teachers training colleges were purposively sampled as participants in the study since this group of respondents were homogeneous and the number was also manageable. However, the questionnaire return rate was $89.4 \%$ comprising of 178 tutors. All the 35 Heads of Departments (HODs) from the seven academic departments in the primary teachers training colleges were purposively selected and interviewed. Stratified and simple random sampling was used to sample the 20 classrooms used for observation as per academic departments. Professional documents used for analysis were purposively sampled as they would provide information with regard to whether tutors integrated societal issues into their teaching as well as if the learning experiences students were exposed provided them with opportunities for interactive activities and community linkages.

A pilot study was conducted in order to establish the consistency of the internal data, ensure clarity of the questions and instructions and determine any flaws and weakness within the research instruments (Arain et al., 2010). Content validity was established by computing the Content Validity Index (CVI) based on five experts' judgement and a content validity index of 0.88 was achieved and was found relevant for the study (Shi, Mo \& Sun, 2012). The validity of qualitative data was determined through data triangulation, repeated observation and longevity of observation (Punch, Noble \& Smith, 2014). Cronbach's Coefficient Alpha (Cronbach, 1951) was used to estimate the reliability of the questionnaire and hence enabled the researcher to modify, restructure and remove any items which were ambiguous. The instrument was accepted as reliable at an alpha level of 0.755 . Constant data comparison was used to check on the reliability of data collected qualitatively (Punch, 2014).

Quantitative data were analysed using descriptive statistics (frequency, mean and standard deviations) and inferential statistics (chi-square test). Qualitative data were analysed using thematic analysis.

\section{FINDINGS AND DISCUSSIONS}

\section{Tutors Preference on Choice of Instructional Approaches}

The study first sought to determine tutors' preference in the choice of instructional approaches they used in teaching. Items based on teacher-centred and learner-centred instructional approaches were given from which tutors were expected to select approaches they frequently used. The results are as presented in Figure 1. 
Figure 1: Tutors Preference in choice of instructional approaches

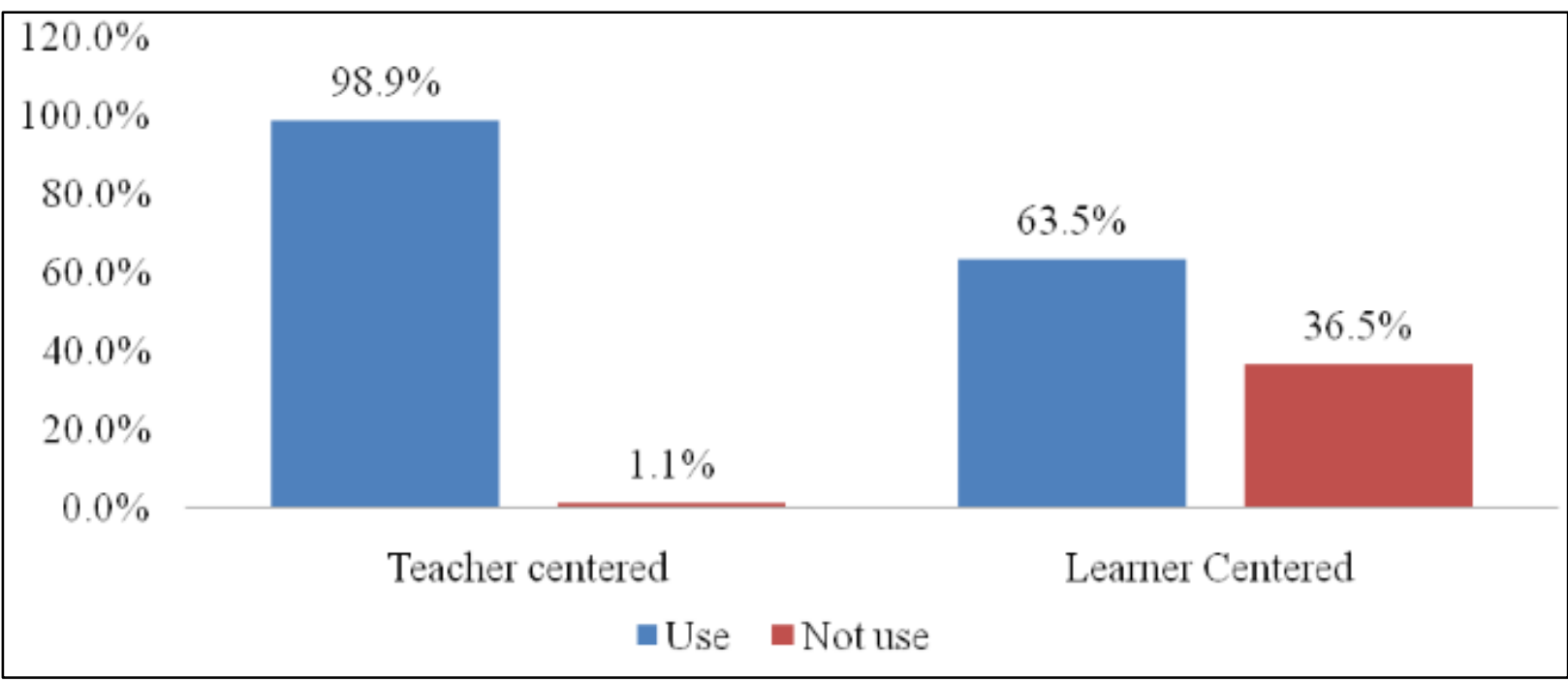

Analysis in Figure 1 shows that majority 176 (98.9\%) of tutors' preferred teacher-centred approaches, while $113(63.5 \%)$ preferred learner-centred. This comparison shows tutors employ both teacher-centred and learnercentred instructional approaches. However, teacher-centred instructional approaches were given more preference by tutors as compared to learner-centred.

This finding is similar to the finding of Williter et al. (2013) whose study found that the majority of tutors used teacher-centred instructional approaches that encouraged recall or memorisation of facts while a few tutors employed learner-centred instructional approaches consistently in their teaching. Kafwa, Gaudience and Kisaka (2015) had also found that the use of teacher-centred instructional approaches in teacher training colleges was dominating.

\section{Tutors Level of Social Reconstruction Orientation to Curriculum}

Secondly, the study sought to determine the level of tutors' social reconstruction orientation to the curriculum. Tutors were required to indicate the extent they agreed to the nine items using five-point Likert scale where $1=$ strongly disagree, $2=$ disagree, $3=$ not sure, $4=$ agree and $5=$ strongly agree on social reconstruction which had been highlighted. Scores of a mean between 1 and 3.4 implied low preference in the belief of a social reconstruction curriculum while scores of a mean between 3.5 and 5 implied a high preference for the belief in social reconstruction curriculum. The findings are presented in Table 1. 
Table 1: Tutors' Level of Social Reconstruction Orientation

\begin{tabular}{|c|c|c|c|c|c|c|c|c|}
\hline $\begin{array}{l}\text { Indicators of social } \\
\text { reconstruction orientation }\end{array}$ & & SD & $\mathbf{D}$ & $\mathbf{N}$ & $\mathbf{A}$ & $\mathbf{S A}$ & Mean & $\begin{array}{l}\text { Std. } \\
\text { Dev }\end{array}$ \\
\hline Teaching ideas are drawn from & $\%$ & 21.9 & 57.9 & 2.2 & 15.2 & 2.8 & 2.2 & 1.034 \\
\hline emerging issues in the society & $\mathrm{n}$ & 39 & 103 & 4 & 27 & 5 & & \\
\hline Issues in society are the most & $\%$ & 6.2 & 36.5 & 14.6 & 29.8 & 12.9 & 3.1 & 1.196 \\
\hline $\begin{array}{l}\text { important content to be included in } \\
\text { the curriculum }\end{array}$ & $\mathrm{n}$ & 11 & 65 & 26 & 53 & 23 & & \\
\hline Teacher trainees are allowed to & $\%$ & 15.2 & 47.2 & 16.9 & 18.0 & 2.8 & 2.5 & 1.042 \\
\hline $\begin{array}{l}\text { carry out investigations, analysis } \\
\text { and evaluation of problems in } \\
\text { society as part of their training }\end{array}$ & $\mathrm{n}$ & 27 & 84 & 30 & 32 & 5 & & \\
\hline Teacher trainees are left to identify & $\%$ & 21.9 & 48.3 & 11.8 & 13.3 & 4.5 & 2.6 & 1.109 \\
\hline $\begin{array}{l}\text { their own choice of school practice } \\
\text { to understand better societal } \\
\text { problems }\end{array}$ & $\mathrm{n}$ & 39 & 86 & 21 & 24 & 8 & & \\
\hline Social reform and responsibility are & $\%$ & 16.9 & 35.4 & 26.4 & 6.2 & 15.2 & 2.7 & 1.28 \\
\hline the primary goals of schooling & $\mathrm{n}$ & 30 & 63 & 47 & 11 & 27 & & \\
\hline The content I teach in my subject is & $\%$ & 24.7 & 38.2 & 16.3 & 12.9 & 7.9 & 2.4 & 1.214 \\
\hline $\begin{array}{l}\text { organised around teacher trainees } \\
\text { needs and interests }\end{array}$ & $\mathrm{n}$ & 44 & 68 & 29 & 23 & 14 & & \\
\hline Emotionally supportive & $\%$ & 26.4 & 41.0 & 11.8 & 12.9 & 7.9 & 2.3 & 1.222 \\
\hline $\begin{array}{l}\text { environment is provided to enhance } \\
\text { trainees learning }\end{array}$ & $\mathrm{n}$ & 47 & 71 & 21 & 23 & 14 & & \\
\hline Opportunities for integration of & $\%$ & 23.0 & 42.1 & 11.8 & 12.9 & 10.1 & 2.4 & 1.257 \\
\hline $\begin{array}{l}\text { trainees affective, cognitive and } \\
\text { psychomotor skills are provided }\end{array}$ & $\mathrm{n}$ & 41 & 75 & 21 & 23 & 18 & & \\
\hline I discuss and interact with my & $\%$ & 27.0 & 36.5 & 12.9 & 25.0 & 9.6 & 2.4 & 1.283 \\
\hline $\begin{array}{l}\text { students as part of solving problems } \\
\text { and addressing issues affecting the } \\
\text { teaching-learning process }\end{array}$ & $\mathrm{n}$ & 48 & 65 & 23 & 14 & 17 & & \\
\hline
\end{tabular}

Table 1 shows the finding on the level of tutors' social reconstruction orientation to the curriculum. The results indicate that tutors' social reconstruction orientation to the curriculum was low in the areas of teaching ideas being drawn from emerging issues in the society $(M=2.2)$; allowing teacher trainees to carry out investigations, analysis and evaluation of problems in the society as part of their training $(M=2.5)$; allowing teacher trainees to identify their own choice of school practice so as to understand better societal issues $(M=2.6)$. Social reform and responsibility are the primary goals of schooling were also low $(M=2.7)$ as well as organising subjects in terms of teacher trainees needs and interests $(M=2.4)$, providing an emotionally supportive environment to enhance teacher trainees learning $(M=2.3)$. Providing opportunities for integration of teacher trainees affective, cognitive and psychomotor skills was equally low $(M=2.4)$, 
also tutors interaction with teacher trainees as part of solving problems and addressing issues affecting the teaching and learning process $(M$ $=2.4$ ) and the belief that issues in the society are the most important to be included in the curriculum $(M=3.1)$. Generally, tutors social reconstruction orientation to curriculum had a low preference as all of the items indicated a mean ranging between 2.2 to 3.1. The standard deviations are suggestive of tutors' agreement in relation to the indicators on tutors' social reconstruction orientation to the curriculum as the deviations between the responses were closely related. This means that tutors in primary teachers training colleges have a low social reconstruction orientation about the teacher education curriculum. It could also mean that tutors from the five colleges where this study was conducted have a low preference for the teaching of societal issues in the teacher education curriculum.

Heads of departments were asked their views on how they perceived a curriculum for social reconstruction in terms of its relevance in developing a holistic teacher. Eighteen (51\%) of the participants from the different departments noted that such a curriculum was significant in addressing issues that were affecting individual teacher trainees. One female HOD in the language department opined that if comprehensive attention was paid in addressing issues that affected student learning such as drug and substance abuse and health-related issues, they would be able to concentrate on their studies. Consequently, their academic achievement would improve. The interview conducted with the HODs revealed that although a curriculum for social reconstruction was relevant in addressing issues pertaining to social responsibility, it was not given much emphasis in the primary teacher education curriculum. One of the participants observed:

A good curriculum should provide a balance between the academic, moral and social lives of the students. It should consider giving them opportunities to explore issues taking place in the society so that when they exit, they can fit in it accordingly. This is contrary to what is happening in teacher training colleges in Kenya as the curriculum does not emphasise on such issues.

Similarly, $20 \%$ of the interviewees expressed their concern about the complexity of a curriculum based on social reconstruction. They viewed it as one that would overload the already overburdened teacher education curriculum with some of the participants citing limited time they had to cover the syllabus. It also emerged that most tutors were not keen on developing teacher trainees' knowledge, skills and attitudes that could help them adjust to society.

The interview findings from $28(80 \%)$ of the participants from the various colleges and departments revealed that due to lack of structured programmes where tutors could interact with the teacher trainees, issues affecting the teacher trainees such as drug and substance abuse, poor performance, lack of self-awareness among other problems were left to the tutor in charge of guidance and counselling or were referred to the discipline committee. However, it is important to note that teacher trainees are meant to be equipped with competencies that would help them handle primary school-going children and hence the 
need to rethink what goes into the teacher education curriculum.

An analysis of the current primary teacher education curriculum showed that the research component was lacking. Most 23(66\%) of participants of the study opined that research was relevant in unfolding issues that affect the education sector in particular and society in general; expose the teacher trainees to most of the social problems and how to solve them as they read and analyse them and provide interactive opportunities between colleges and communities, consequently exposing the teacher trainees to the many issues that take place in the society. The interviews also reviewed that tutors had limited time to expose the teacher trainees to community projects. However, most of the HODs interviewed observed that if the teacher trainees were given the opportunity to decide on their choice of schools for carrying out the teaching practice, it would provide them a period within which to interact with the school and community around and learn from such exposure. However, such community linkage approaches were not within the scope of the prevailing primary teacher education. One participant noted:

The students have limited opportunities for interacting with the communities because the programme is strict. Consequently, they are not exposed and they relate less with the community around the college. Perhaps, if the students were more exposed by even linking up with the nearest primary school where the students could visit at least a fortnight and develop their competencies, skills and knowledge, we would be able to analyse their social responsibility. The three weeks they take their teaching practice then break is so limited to allow us to guide them on social issues.

This response was given by many of the participants implying the underlying gaps that existed between the primary teacher education curriculum and the expectation of a curriculum whose one of the objectives is to prepare teachers who can develop child's ability and imaginative thinking in problem-solving and self-expression and one that can adapt to change and new environments, has professional commitment and competence. This finding could also mean that tutors have a low preference for a social reconstruction curriculum and hence the limited organisation of programmes in colleges that can enhance the social experiences of the teacher trainees.

The overall tutor belief of the social reconstruction curriculum in this study was found to be low. This can be attributed to the less emphasis on social issues in the curriculum. The findings of this study are in agreement with the findings of Capel's (2015) study that found teachers to have the least orientation to social reconstruction curriculum. The study findings, however, differ from the findings of Ennis and Chen (2013) study that found teachers particularly those in rural settings to be more oriented towards social reconstruction and that curriculum was shaped to reflect both opportunities and constraints experienced in the two diverse societies; that is rural and urban societies. Similarly, Ashour et al. (2012) found that the curriculum in place fostered students' abilities to criticise societal problems and create new and healthy societies and thus, teachers gave a high priority to social reconstruction. Other study findings such as Cheung and Ng (2000) and Farahani and 
Maleki (2014) also differed from the findings of the present study as teachers in these studies were found to be highly oriented towards social reconstruction.

Bagh (2014) argues that educators should use academic disciplines as they facilitate students to identify social issues, help them to critically examine, understand and analyse the social issues and instil in them problem-solving skills to be able to address the social issues. Tutors can use several mechanisms to ensure that the teacher trainees have acquired social competencies adequate enough to enable them to understand social problems that exist in societies and be able to solve them. Dewey (1916) one of the proponents of curriculum development recommended that teachers should use the demands and challenges of the social institutions in which students find themselves to stimulate the students' power to effect social reforms. However, the findings of the present study differed from the suggestions of Bagh (2014) and Dewey (1916) as tutors minimally involved teacher trainees in programs that could expose them to the understanding of societal issues.

Schiro (2013) further highlights that teacher educators should facilitate dialogue using both cognitive and affective questions to help students collect, analyse and critique societal issues. Schiro (2013) adds that teacher educators should also help students to clarify their values and how these affect their decisions on what actions they take. McGregor (2019) opines that teacher educators should build a collaborative relationship with the students to build their courage and confidence in taking a stand on social injustice and other issues constraining the society, consequently leading to a creative restructuring of societal problems. These arguments differed from the finding of the current study as it was found that tutors least engaged teacher trainees in dialogues and related collaborative activities such as community linkages for purposes of enhancing their understanding of challenges facing the society.

Additionally, McGregor (2019) argues that teacher educators have a role in ensuring that the students cooperate with their local community and neighbourhood either through arts, service learning or participatory action so that they learn independence and social consensus or at the same time gain autonomy, inner power and self-efficacy needed to effect social change. This shows it is possible to implement a curriculum that focuses on social reconstruction, and it is the responsibility of teacher training colleges as these are social institutions. Such a curriculum would add more meaning to the lives of the teacher trainees as it represents real-life experiences that they are living within. The competency-based teacher education framework proposes that teachers should innovatively use strategies that change learners' mindsets by letting students take risks, using flipped classroom model, inviting entrepreneurs and innovators into the classroom and using the design thinking process to uncover new ideas in the multifaceted environments.

\section{Relationship between Tutors' Social Reconstruction Orientation and Choice of Instructional Approaches}

Chi-square analysis was conducted to establish the relationship between tutors' social reconstruction orientation and choice of 
East African Journal of Interdisciplinary Studies, Volume 3, Issue 1, 2020

Article DOI: https://doi.org/10.37284/eajis.3.1.268

instructional approaches. Results are as presented in Table 2.

Table 2: Social Reconstruction and Choice of Instructional Approach

\begin{tabular}{llll}
\hline & Value & df & Asymp. Sig. (2-sided) \\
\hline Pearson Chi-Square & $16.725^{\text {a }}$ & 14 & .271 \\
Likelihood Ratio & 19.452 & 14 & .148 \\
Linear-by-Linear Association & .903 & 1 & .342 \\
N of Valid Cases & 178 & & \\
\hline
\end{tabular}

Results in Table 2 show that there was no significant relationship $\left(\chi^{2}=16.725, d f=14, p\right.$ $=0.271$ ) between social reconstruction and the choice of instructional approaches. The study concludes that tutors' social reconstruction orientation has no statistically significant relationship with the choice of instructional approaches used in public primary teachers' training colleges in Kenya.

This finding could be deduced to imply that tutors have their beliefs, assumptions or dispositions about the teaching of social issues in the curriculum which is not influenced by having such issues in the curriculum and therefore due to their formed curriculum orientation the instructional approaches tend not to influence how they teach such issues.

Chen and Schmidtcke (2017) found that although teachers were aware they were to teach students how to fit in the society, they did not but rather prefer to teach them for purposes of passing examinations and getting jobs. The Chen and Schmidtcke (2017) study, however, differed from the findings of this study in that in their study they found teachers to use teacher centred instructional approaches, findings that this study did not find to be influenced by social reconstruction orientation.
Generally, the results show that social reconstruction did not fully influence the choice of instructional approaches. This finding differs from the study of Farahani and Maleki (2014) that found lecturers to be oriented to social reconstruction and perceived curriculum development to be learner-centred. The study findings, however, are in tandem with the study by Mclaughlin and Sharlene (2011) whose study found that despite teachers' knowledge and awareness of the social problems affecting the lives of the students, they did not engage the students in discussing means to solve the problems as they lacked the confidence to do so. Mclaughlin and Sharlene (2011) further found that the teachers' lack of confidence was a result of the local contextual factors as well as their own beliefs about the curriculum implementation process.

\section{CONCLUSION AND RECOMMENDATIONS}

The inadequate representation, the restricted framework, limited provision of interactive learning activities and policy on the integration of societal issues in the primary teacher education curriculum provided a poor link between theory on societal issues and practice. This had implications on the teaching of the societal issues in the teacher education curriculum as tutors were discovered to teach it 
theoretically. This is likely to affect the achievement of teacher education objectives that require teacher trainees to develop competitively in knowledge, skills, values and attitudes. Limited exposure to social knowledge, skills, values and attitudes disadvantages an individual's holistic development and would imply low learning outcomes and consequently, the low quality of teacher education offered.

When the trainees have not been empowered on social competences, they will be faced with several problems they may be unable to solve on a daily basis and may fail to adjust to the ever-changing global demands. This puts into question the quality of teacher education. Reforms on the teaching and learning environment at teacher training colleges as well as stakeholder engagement are crucial in changing the mindsets of the tutors with regard to the teaching of societal issues. These changes will also be vital in encouraging tutor -trainee interactive engagement, thus improving the achievement of teacher education objectives.

It is very important that tutors are well prepared and motivated to carry out research and publication as colleges prepare to move to the competency-based curriculum (CBC). This will help to bring out sustainable innovation that could improve the quality of primary teacher education. Through research issues that affect learning including contemporary issues in the society will be addressed. That way, tutors will be able to demonstrate and also engage teacher trainees in providing solutions to the education sector and improve on it. This will also help tutors to change their mindset about a social reconstruction curriculum and effectively teach on values and attitudes. The Ministry of Education in collaboration with the Kenya Institute of Curriculum Development (KICD) and Teachers Service Commission (TSC) should organise for comprehensive training of tutors on the area of research and publication before tutors embark on teaching this component.

Teacher training colleges should establish community and industrial linkages to enable them to establish gaps that exist between the teacher education curriculum and real-life experiences. This will be important in developing key competencies in teacher trainees, among them, professional knowledge, skill and social competencies. In connection to this, KICD should help colleges to effect this aspect by regularly reviewing the teacher education curriculum to improve on its content, structure and relevancy. This will ensure that the curriculum is up to date and individual and societal needs are addressed for efficiency and effectiveness in teaching through stakeholder engagement.

\section{REFERENCES}

Abakay, U., Şebin, K., \& Şahin, M. Y. (2013). Curriculum Orientations of pre-service physical education teachers. Life Science Journal, 10(3), 13-23.

Aloni, N. (2013). Empowering dialogues in humanistic education. Educational Philosophy and Theory, 45(10), 1067-1081.

Arain, M., Campbell, M. J., Cooper, C. L., \& Lancaster, G. A. (2010). What is a pilot or feasibility study? A review of current practice and editorial policy. BMC medical research methodology, 10(1), 1-7. 
Ashour, R., Khasawneh, S., Abu-Alruz, J., \& Alsharqawi, S. (2012). Curriculum orientations of pre-service teachers in Jordan: a required reform initiative for professional development. Teacher Development, 16(3), 345-360.

Bagh, M. E. (2014). An investigation of teachers' experience of applying Community Action Projects in the discipline of Humanities in a Victorian Catholic Secondary School. Australian Catholic University.

Ballantine, J. H., \& Hammack, F. M. (2015). The sociology of education: A systematic reader $\left(7^{\text {th }}\right.$ Ed). New York \& London: Routledge.

Bay, E., Gundogdu, K., Dilekci, D., Ozan, C. \& Ozdemir, D. (2011). Investigation of elementary teachers' curriculum and instruction congress. Bolu, Turkey: Abant Izzet Baysal University.

Brendan, M. (2016). Understanding curriculum. Asian Journal of Humanities and Social Studies, 4(4), 2321-2799.

Broome, J. L. (2014). Commentary-The case for humanistic curriculum: A discussion of curriculum theory applied to art education. Journal of Art for Life, 5(1), 11-33.

Capel, S. (2016). Value orientations of student physical education teachers learning to teach on school-based initial teacher education courses in England. European Physical Education Review, 22(2), 167-184

Chen, P. \& Schmidtke, C. (2017). Humanistic Elements in the Educational Practice at a United States Sub- Baccalaureate Technical
College. International Journal for Research in Vocational Education and Training. 4(2), 117-145.

Cheung, D., \& Ng, P. H. (2000). Science teachers' beliefs about curriculum design. Research in Science Education, 30(4), 357375.

Creswell, J. W. (2012). Educational research: planning, conducting and evaluating quantitative and qualitative research (4th ed.) Boston, MA: Pearson

Cronbach, L. J. (1951). Coefficient alpha and the internal structure of the test. Psychometrika, 16(3), 297-334.

Dewey, J. (1916). Democracy and Education. New York, NY; Macmillan

Edupedia. (2018, June 10). What is Social Reconstructionism? Retrieved from Edupedia:

https://www.theedadvocate.org/edupedia/c ontent/what-is-social-

reconstructionism/\#: :text=What $\% 20$ is $\% 2$ 0Social\%20Reconstructionism\%3F\%20\%20Edupedia,What\%20is\%20Social\%20R econstructionism $\% 3 \mathrm{~F} \&$ text $=\mathrm{Is} \% 20 \mathrm{an} \% 20 \mathrm{e}$ ducational $\% 20$ philosophy\%20that,curricul um\%20that $\% 20$ fosters $\% 20$ their\%20develo pment.

Ennis, C. D., \& Chen, A. (1995). Teachers' value orientations in urban and rural school settings. Research quarterly for exercise and sport, 66(1), 41-50.

Farahani, M. F., \& Maleki, M. (2014). A survey on the tendency toward curriculum ideologies among academic board members in educational sciences faculties-Tehran 
2010-11. Procedia-Social and Behavioural Sciences, 116, 2392-2396.

Hunkins, F. P., \& Ornstein, A. C. (2016). Curriculum Foundations, Principles and Issues. Pearson Education.

Kafwa, N. O., Gaudience, O., \& Kisaka, S. T. (2015). Teacher Preparation Practices in Kenya and the 21st Century Learning: A Moral Obligation. Journal of Education and Practice, 6(17), 1-8.

Kaur, B. (2012). Equity and Social Justice in Teaching and Teacher Education. Teaching and Teacher Education, 28(2), 485-492.

Kenya Institute of Curriculum Development (KICD). (2019). Teacher Education Curriculum Framework-Masada Draft. Retrieved from https://kicd.ac.ke.pdf

Lindsay, B., \& Ginsburg, M. B. (2013). The political dimension in teacher education: Comparative perspectives on policy formation, socialisation and society (Vol. 5). Routledge.

Mayne, H. (2014). The Social Reconstructionist Approach to Teacher Education: A Necessary Component to Achieving Excellence and Quality Education for All. Research in Comparative and International Education, 9(10), 48-55

McGregor, S. (2019). Education for Sustainable Consumption: A Social Reconstruction Model. Canadian Journal of Education, 43(2), 745-766

McLaughlin, C., \& Swartz, S. (2011). Can we use young people's knowledge to develop teachers and HIV-related education?. Prospects, 41(3), 429-444

Mills, C. (2012). When Picking the Right People is not enough: A Bourdieuian Analysis of Social Justice and Dispositional Change in Pre-Service Teachers. International Journal of Education Research, 53(1), 269-277

Mosley, M. (2010). Becoming a literacy teacher: Approximations in critical literacy teaching. Teaching Education, 21(4), 403426.

Orpinas, P. (2010). Social Competence. In The Corsini Encyclopaedia Of Psychology $\left(4^{\text {th }}\right.$ edition, Vol 4)

Punch, K. F. (2014). Introduction to research methods in education. London: Sage publications.

Reddy, M. (2014). The best teachers enable the students to teach themselves. The Age.

Schiro, M. (2013). Curriculum Theory: Conflicting Visions and Enduring Concerns $\left(2^{\text {nd }}\right.$ ed) Thousand Oaks, CA: Sage Publications Inc.

Shi, J., Mo, X., \& Sun, Z. (2012). Content validity index in scale development. Journal of Central South University. Medical sciences, 37(2), 152.

Shrivastava, S. K. (2017). Promotion of moral values through education. International Journal of Research in Social Sciences, 7(6), 103-108.

Sukri, A., Rizka, M. A., Sakti, H. G., Maududy, K. U., \& Hadiprayitno, G. (2018). Designing an integrated curriculum based 
on local primacy and social reconstruction perspectives of West Nusa Tenggara, Indonesia. Jurnal Pendidikan IPA Indonesia, 7(4), 467-475.

Ticknor, A. S. (2015). Sustaining Social Justice Learning: What Teacher Educators Can Do. Journal of Critical Thought and Praxis, 4(1), 1-15.

Williter, R. P. Ahmed, O. \& Kipng'etich, K. J. E. (2013). Towards Learner Centred Pedagogies by Teacher Educators in Kenya: A Study of Kericho Teachers' Training College. International Journal of Asian Social Science, 3(1), 255-265. 